\title{
Integrated cultural practices for whitefly management in organic tomato
}

\author{
Pedro Henrique Brum Togni ${ }^{1}$ (D) | Waldir Aparecido Marouelli ${ }^{2}$ | \\ Alice Kazuko Inoue-Nagata ${ }^{2}$ | Carmen Silvia Soares Pires ${ }^{3}$ | Edison Ryoiti Sujii ${ }^{3}$
}

\author{
${ }^{1}$ Departamento de Ecologia, Universidade de \\ Brasília, Brasília, DF, Brazil \\ ${ }^{2}$ Embrapa Hortaliças, Gama, DF, Brazil \\ ${ }^{3}$ Embrapa Recursos Genéticos e \\ Biotecnologia, Brasília, DF, Brazil

\section{Correspondence} \\ Pedro Henrique Brum Togni, Departamento \\ de Ecologia, Instituto de Ciências Biológicas, \\ Universidade de Brasília (UnB), Campus \\ Universitário Darcy Ribeiro, Asa Norte, \\ Brasília, DF 70910-900, Brazil. \\ Email: pedrotogni@unb.br

\section{Funding information} \\ Centro de Desenvolvimento Tecnológico \\ da Agricultura Orgânica no Distrito- \\ CDTOrg; Fundação de Apoio à Pesquisa \\ do Distrito Federal; Conselho Nacional de \\ Desenvolvimento Científico e Tecnológico
}

\begin{abstract}
The whitefly Bemisia tabaci (Hemiptera: Aleyrodidae) is a serious pest among the diverse insect fauna of the tomato crop, especially when cultivated in organic systems. The feeding behaviour of $B$. tabaci is responsible for direct damage to tomato plants and for the transmission of several viruses, such as begomoviruses. The objective of this study was to evaluate the effect of integrating the cultural practices of intercropping and irrigation systems on $B$. tabaci abundance and the incidence of begomovirus in organic tomato systems. Field experiments were performed in the dry season for 2 years when $B$. tabaci abundance and begomovirus incidence were compared in tomato crops planted either in monoculture or intercropped with coriander and irrigated by overhead sprinklers or by a drip irrigation system. Tomato plants intercropped with coriander and irrigated by overhead sprinklers showed the lowest levels of $B$. tabaci colonization by adult and nymph densities. Most likely, the coriander plants produced visual and olfactory barriers for insect host plant selection, and the overhead sprinkler irrigation physically interfered with the movement and establishment of the insects. The combined effect of intercropping and sprinkler irrigation made tomato plants less suitable for B. tabaci establishment. Moreover, tomatoes intercropped with coriander and irrigated by sprinkler irrigation also reduced the incidence of begomovirus-infected plants. In summary, integrating tomato-coriander intercropping and sprinkler irrigation can help manage B. tabaci and associated viruses in organic tomato crops.
\end{abstract}

\section{KEYWORDS}

insect-plant interaction, Bemisia tabaci, begomovirus, coriander, intercropping, sprinkler irrigation, agroecology

\section{1 | INTRODUCTION}

Manipulating plant diversity, such as intercropping commercial plants, is an important pest management strategy that could be combined with other cultural practices to prevent pest damage. This is particularly relevant for the management of insects that act as virus vectors such as the whitefly Bemisia tabaci (Gennadius) MEAM1 (Middle East Asia Minor 1 species, formerly biotype B) (Hemiptera: Aleyrodidae) (hereafter B.tabaci) (Angelella, Holland, \& Kaplan,
2016; Maruthi, Jeremiah, \& Muhammed, 2016). Whiteflies are able to cause severe damage to agricultural crops, even at low population levels, so a delay in crop colonization is imperative to reduce economic losses (Oliveira, Henneberry, \& Anderson, 2001). Only in Brazil, the annual estimated economic loss caused by $B$. tabaci is US\$ 714 million (Oliveira, Auad, Mendes, \& Frizzas, 2013).

Bemisia tabaci is a highly polyphagous phytophagous insect that feeds on several weeds, cultivated plants and noncultivated plants worldwide (Byrne \& Bellows, 1991; EFSA, 2013; Oliveira et al., 2001). 
This insect can cause direct damages by continuous sap sucking, which induces plant physiological disorders, and by excreting honeydew that accumulates over several parts of the plant (Gilbertson, Batuman, Webster, \& Adkins, 2015). Nevertheless, the viruses transmitted by $B$. tabaci inflict the most serious damage to crops. This insect species can transmit more than 110 virus species, most of which are in the genus Begomovirus (family Geminiviridae) (Gilbertson et al., 2015; Jones, 2003; Navas-Castillo, Fiallo-Olivé, \& Sánchez-Campos, 2011). These viruses induce symptoms such as leaf curling, chlorosis, mosaic and stunting in many important crops (Díaz-Pendón et al., 2010). Recently, whiteflies were also named the "supervector" of plant viruses due to their widespread distribution and high efficiency in transmitting several viruses (Gilbertson et al., 2015).

Begomoviruses are transmitted in a persistent and circulative manner by B. tabaci. Once B. tabaci acquires the virus by feeding on an infected plant, the virus moves into the insect's salivary glands from which the virus particles can be transferred to other plants during the entire lifespan of the whitefly (Ghanim \& Medina, 2007; Pakkianathan et al., 2015). The B.tabaci-begomovirus interaction enables the virus to spread into many new habitats and hosts using the dispersal abilities of its vector even over long distances (Czosnek, Ghanim, \& Ghanim, 2002; Ning et al., 2015; Polston, Chellemi, Schuster, McGovern, \& Stansly, 1996). The relationship between vector and virus produces a primary and secondary virus spread in the crop. The primary virus spread occurs when migrant viruliferous $B$. tabaci adults visually recognize specific light wavelengths, which induces a photokinetic response (descendant flight) in the area (Byrne, 1999; Isaacs, Willis, \& Byrne, 1999; Riis \& Nachman, 2006). A viruliferous whitefly colonizing a new habitat can efficiently transmit begomoviruses to the plants while feeding (Liu et al., 2013). After this primary viral spread, virtually all nonviruliferous whiteflies (nymphs, migrants and newly emerged adults) that feed on an infected plant can acquire the virus (Díaz-Pendón et al., 2010). Therefore, the primary virus spread occurs when migrant whiteflies are evaluating a given host or habitat to feed and reproduce. Following host or habitat acceptance, the whitefly population dynamic is closely related to local factors, such as wind, temperature, spatial heterogeneity (Brewster, Allen, Schuster, \& Stansly, 1997) and semiochemical recognition (Bleeker et al., 2009; Togni, Laumann, Medeiros, \& Sujii, 2010). Each of these factors acts as an arrestant stimulus to retain the insect in the area so that individuals tend to exhibit only shortrange flights among plants (Byrne, 1999). This short-range flight associated with the virus-infected plants in the primary spread is responsible for a secondary spread in the crop (Brewster et al., 1997).

Tomato (Solanum lycopersicum L.) (Solanaceae) is widely cultivated in South America, and yield losses caused by begomoviruses can reach $100 \%$ (Oliveira et al., 2013). Severe damage caused by the begomovirus isolates from South America occurs mainly when the plants are infected up to 30-45 days after transplanting (Giordano, Fonseca, Silva, Inoue-Nagata, \& Boiteux, 2005).

In organic farming, chemical insecticides are prohibited, and the use of alternative cultural practices that can prevent the establishment of migrant viruliferous whiteflies are demanded, particularly during initial stages of tomato crop development. In Brazil, fresh tomato fruits are produced mainly by small growers, and due to the lack of alternatives for crop production in organic systems, growers usually adopt the similar cultural practices used in the conventional system. Thus, the crop is planted in monoculture and is irrigated by the drip system with several nonchemical insecticides. However, in Costa Rica, intercropping of tomatoes with coriander (Coriandrum sativum L.) (Apiaceae) was efficient in reducing the number of whiteflies and whitefly-transmitted virus incidence in a conventional tomato field (Hilje \& Stansly, 2008). As coriander is planted before tomato plants, coriander plants can visually mask tomato plants from whiteflies. After that, Togni et al. (2009) demonstrated that this intercropping approach could be suitable for whitefly management in conventional and organic tomato crop systems in Brazil. This intercrop was considered more efficient in the organic system due to the reduction in whitefly nymphs, most likely caused by the presence of a more diverse and abundant fauna of predators and parasitoids in the organic system (Togni et al., 2009; Togni, Cavalcante, et al., 2010). In addition to this, coriander volatiles produce an odour-masking effect that can make it difficult for whiteflies to find tomato volatiles (Togni, Laumann, et al., 2010). Irrigation management is another agricultural practice that can be integrated into the intercropping system to reduce insect infestations. The use of an overhead sprinkler irrigation was found to reduce the number of whitefly nymphs and adults in cotton fields (Castle, Henneberry, \& Toscano, 1996) and was identified as an important mortality factor due to dislodgment of the eggs and nymphs from the plants (Naranjo \& Ellsworth, 2005). In Brazil, some organic growers reported the use of sprinkler irrigation to manage pests and diseases in several crops, including tomato (Sousa et al., 2016).

Despite the intercropping with coriander plants and use of a sprinkler irrigation showing promising results in organic cropping systems, there is no evidence that these strategies could be combined to strengthen the positive effects of reducing the abundance of B. tabaci and the incidence of begomoviruses. To test these assumptions, the abundance and dispersion patterns of whiteflies and the incidence of begomoviruses were evaluated for 2 years in an experimental field with an organic tomato cropping system in a tropical region. The following questions were addressed as follows: (a) Can plots of tomato plants intercropped with coriander plants reduce the abundance and affect the dispersion of B. tabaci in organic tomato crops? (b) If so, can the use of overhead sprinklers broaden these effects? (c) Can the combined use of intercropping and sprinkler irrigation reduce begomovirus incidence in tomato plants?

\section{2 | MATERIALS AND METHODS}

\section{1 | Location}

This study was conducted in the Organic Vegetable Research and Production Area of Embrapa Vegetables, located in the Federal 


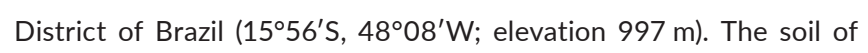
the experimental area is classified as typical dystrophic red latosol, Cerrado phase, with a clay texture (Marouelli, Medeiros, Souza, \& Resende, 2011). The climate of the region is type Cwa, a semihumid temperate climate with dry winters and hot summers, according to the Köppen-Geiger classification (Nimer \& Brandão, 1989). Experiments were conducted during the dry season (May-October), a period when average temperatures vary from 15 to $30^{\circ} \mathrm{C}$, the relative humidity can fall to below $15 \%$, and the rainfall is $<100 \mathrm{~mm}$, which are conditions that favour insect pest outbreaks in this region. The negative evapotranspiration balance and the low relative humidity during the dry season reduce the incidence of fungal and bacterial diseases in the tomato crop and allow the use of sprinkler irrigation systems to supply water to the plants (Marouelli, Medeiros, et al., 2011).

\section{2 | Experimental design}

Tomatoes were cultivated in two different organic cropping schemes (monoculture and intercropped with coriander) in two different experiments, carried out in 2008 and 2009, respectively. In the first experiment, each experimental plot covered an area of $100 \mathrm{~m}^{2}(10 \times 10 \mathrm{~m})$ and contained 10 rows of plants, each $10 \mathrm{~m}$ in length, totalling 200 plants in six replicates per treatment. As the experimental area was being used for other experiments to evaluate the effects of irrigation management on tomato fruit production in 2008, in half of the plots (three for each treatment), plants were irrigated by the drip system and half irrigated by the overhead sprinkler irrigation system, forming two continuous blocks according to the irrigation system. We sampled plots with both irrigation systems in order to increase the number of replicates per treatment in this year. However, due to the spatial arrangement, of the plots, the influence of the irrigation system on B. tabaci abundance was not evaluated to avoid pseudoreplication. We then used the irrigation system as a random factor in our analysis of the B. tabaci abundance data on monoculture and intercropped plots in the first experiment. The plot disposal did not influence our analysis of $B$. tabaci distribution patterns because we constructed contour maps of $B$. tabaci abundance distribution of the whole experimental area, and this analysis was not dependent on the treatments disposal because it is a descriptive analysis rather than an inferential statistic that must follow specific sampling designs to be validated (see Statistical Analyses below). As we observed that the irrigation system could affect the adults' spatial distribution in the first trial, we conducted another experiment to evaluate the combined effect of intercropping and irrigation system on whitefly management in the subsequent year. Hence, in the second experiment, in 2009, tomatoes were cultivated in monoculture and intercropped with coriander and were also irrigated by the drip and overhead sprinkler irrigation. To explicitly evaluate the combined effects of intercropping and irrigation management on B. tabaci abundance and damage, in the second year, we changed the experimental design. The size of the plots was reduced to $50 \mathrm{~m}^{2}$ to accommodate the four treatments with six replicates each. The monoculture and intercropped plots irrigated by the drip or sprinkler irrigation system were randomly distributed in the area, forming completely independent treatments, and plot disposal in the blocks was completely abandoned to allow the proper use of inferential statistics. Care was taken to adjust the sprinklers to avoid any influence on neighbour plots. Therefore, in the first year, the treatments were tomato plants in monoculture or intercropped with coriander. In the second year, the treatments were (a) tomato plants in monoculture irrigated by drip tubes, (b) tomato plants in monoculture irrigated by sprinklers, (c) tomato plants intercropped with coriander plants irrigated by drip tubes and (d) tomato plants intercropped with coriander plants irrigated by sprinklers.

Borders of at least $6 \mathrm{~m}$ of forage sorghum (Sorghum bicolor (L.) Moench.) (Poaceae) and sunn hemp (Crotalaria juncea L.) (Fabaceae) were planted around the plots as windbreaks and physical barriers against pests and to increase biological diversity in the cropping system 20 days before the beginning of the experiment. Thus, the barrier crops were taller than the main crop when the experiments started. Additionally, contour lines running alongside the experimental area were established previously with Mexican sunflower (Tithonia diversifolia [Hemsl.]) (Asteraceae) and elephant grass (Pennisetum purpureum Schum.) (Poaceae).

\subsection{Crop management and irrigation system}

Prior to the tomato planting date in both years, sunn hemp and sorghum were cultivated in the experimental field as green manure and incorporated into the soil approximately 1 month before sowing the coriander. Thirty-five-day-old tomato seedlings of cv. Pollyana (first experiment) and cv. Duradoro (second experiment) were transplanted during the first week of May in both years. Both tomato varieties we used in the experiments are susceptible to begomovirus infection (Embrapa, 2014). A simple row system was adopted, with $1 \mathrm{~m}$ between the plant rows and $0.50 \mathrm{~m}$ between the plants. Tomato plants were vertically staked using tape and trained with one stick per plant. Coriander (cv. Verdão) was hand-sown in all intercropping plots 2 weeks before the tomato seedlings were transplanted, using approximately $5 \mathrm{~g}$ of seeds per linear metre along the row.

Coriander plants were harvested approximately 50 days postplanting in both years, but approximately six coriander plants were left to bloom between every pair of tomato plants. Coriander was then sown again, and the plants were harvested at approximately 50 days after sowing, again leaving some of the coriander plants to bloom. This sowing and harvesting strategy maintained the flowering of coriander plants during almost the entire tomato crop cycle and was intended to attract several natural enemy species (Togni, Cavalcante, et al., 2010).

In plots irrigated by the overhead sprinkler system above the plant canopy, impact sprinklers with openings of $5 \times 8 \mathrm{~mm}$, a spacing of $18 \times 12 \mathrm{~m}$, a working pressure of $250 \mathrm{kPa}$ and an application intensity of $23.5 \mathrm{~mm} / \mathrm{hr}$ were used. In the drip-irrigated experimental plots, there were two drip tubes with openings spaced $0.2 \mathrm{~m}$ apart, a working pressure of $1.0 \mathrm{kgf} / \mathrm{cm}^{2}$ and a flow rate of $1.4 \mathrm{~L} / \mathrm{hr}$ per row of tomato 
(and coriander) plants. Irrigation was performed whenever the water tension in the soil, which was evaluated at $40 \%-50 \%$ of the effective root depth of the tomato plants, reached the pre-established trigger tensions of 15 and 30 kPa (Marouelli, Carrijo, Souza, \& Silva, 2011).

\subsection{Data collection}

Yellow sticky traps, measuring $10 \times 12.25 \mathrm{~cm}$, were used to monitor the number of whitefly adults in the experimental plots during the first 5 weeks after tomato transplantation. Eight traps were used per plot in the first trial, but this number was reduced to four traps per plot in the second trial due to the reduction in the plot size. The traps, which were attached to wooden posts and spaced at least $4 \mathrm{~m}$ apart, were always placed at the height of the plant canopy between two tomato plants. The traps were replaced once a week, and the adult whiteflies were counted manually.

Direct sampling of live adults on plants was performed in the first experiment to produce the contour maps necessary to describe the abundance pattern of the adult whiteflies in a spatially explicit model. A total of 64 tomato plants were evaluated in each plot, and the live adults on the entire plant were counted on week five. The spatial position of each plant was registered. We used this period for sampling because it was assumed that the migrant population was already established in the area. Moreover, the analysis of the population distribution pattern using abundance maps required more than 50 sampling points (Liebhold, Rossi, \& Kemp, 1993), which could be achieved only by the direct sampling of adults over the plants.

The direct sampling of nymphs was conducted to evaluate whether the cropping schemes and irrigation systems had significant effects on adult oviposition behaviour. To accomplish this objective, 15 tomato plants were randomly sampled in each experimental plot weekly during five consecutive weeks. The first sampling occurred 6 weeks after tomato transplantation. The number of nymphs was registered on five leaves per plant, which were sampled randomly around the tomato plant from the bottom to the half-height of the plant.

The incidence of tomato plants with symptoms of begomovirus infection was recorded during the first harvest period approximately 90 days after transplanting in both experiments. The infection was confirmed by testing each sample by dot-blot hybridization (InoueNagata, Albuquerque, Rocha, \& Nagata, 2004). The proportions of plants infected in each plot were measured and compared between the treatments in both years. In both trials (2008 and 2009), we randomly collected 50 adult whiteflies per year and used them to identify the whitefly species using RAPD markers, as proposed by Lima, Campos, Moretzsohn, Návia, and Oliveira (2002). In both years, we randomly collected the adults on different tomato plants at different positions and treatments in the experimental area.

\section{5 | Statistical analyses}

To assess whether intercropping with coriander affected the mean number of adults per trap and the density of nymphs per plant in the first trial, we fitted the data to a linear mixed-effect model (LME) separately for each variable (Crawley, 2007). In this model, we used the mean number of adults per trap and the density of nymphs per plant as dependent variables and the cropping scheme (monoculture or intercropping) as independent variables. The mean numbers of adult whiteflies and nymphs were calculated based on the density per plot throughout the entire sampling period. Therefore, the sampling date and the irrigation system were used as random variables in the model. To assess whether intercropping and irrigation management affected the mean number of adults per trap and the density of nymphs per plant in the second trial, we used a similar procedure. We evaluated whether the number of adults per trap and the density of nymphs per plant (dependent variables) were affected by all possible interactions between the cropping scheme and the irrigation system (independent variables). The sampling date was used as random factor in the model. When any parameter or interaction between parameters did not affect the dependent variables, it was removed from the model, and a new model was fitted. The new model was compared to the full model using an $F$ test, and the analyses continued from the simplest model until obtaining a minimal adequate model (Crawley, 2007). Differences among treatments were determined by model contrast analysis (Crawley, 2007).

To evaluate the distribution patterns of B. tabaci in the experimental area in the first experiment, we constructed contour maps of adult abundance separately from plots irrigated by drip irrigation and sprinkler irrigation for a better visualization. Abundance data were obtained from the counts of live adults in the first experiment. Semivariogram models were fitted separately for each set of experimental plots, as described in Liebhold et al. (1993). When spatial dependence among data was obtained, the contour maps were constructed from an ordinary kriging analysis using the equation $\hat{Z}_{(X 0)}=\sum n_{(i)}\left[\lambda_{i} \cdot z_{(X i)}\right]$, where $\hat{Z}_{(X))}$ is the semivariogram value estimated from unsampled sites, $n$ is the total number of tomatoes sampled, $z_{(X i)}$ is the abundance of B. tabaci adults on each plant and $\lambda_{i}$ is the weight attributed to each $z_{\left(X_{i}\right)}$ value. The kriging calculation attributes weight to the known sampled sites to provide a linear estimation for unsampled locations through data interpolation (Liebhold et al., 1993). Thus, the data interpolation in this analysis produces a probabilistic random function model that can estimate $B$. tabaci abundance on unsampled plants.

The proportions of plants with begomovirus symptoms were compared among treatments by a generalized linear model (GLM) with a declared error distribution (+Error), separately for each year using the plot position as the error source (Crawley, 2007). In this analysis, the proportions of begomovirus-infected plants were used as dependent variables, and the cropping scheme (2008 and 2009) and the irrigation system (2009) were used as independent variables. The significance of the model was tested using an $F$ test, and the significance of the variables was tested by contrast analysis, as described for the LME analysis.

The semivariogram and kriging analyses to construct the contour maps were performed using GS+ software (Gamma Design). The software R ( $R$ Core Team, 2017) was used for the LME and GLM analyses. 

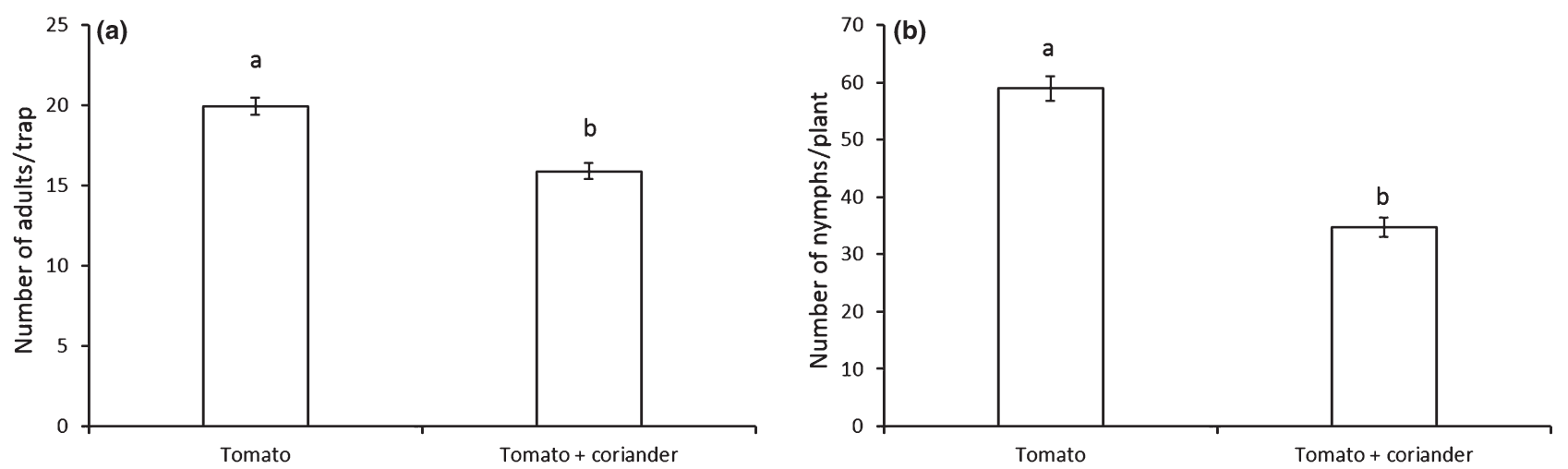

FIGURE 1 Number of adult whiteflies per yellow sticky trap (mean $\pm S E$ ) (a) and number of nymphs (mean $\pm S E$ ) per plant (b) on tomato crops planted in monoculture or intercropped with coriander in an organic system in the Federal District, Brazil. Means followed by the same letter do not differ significantly by model contrast analysis $(p>0.05)$
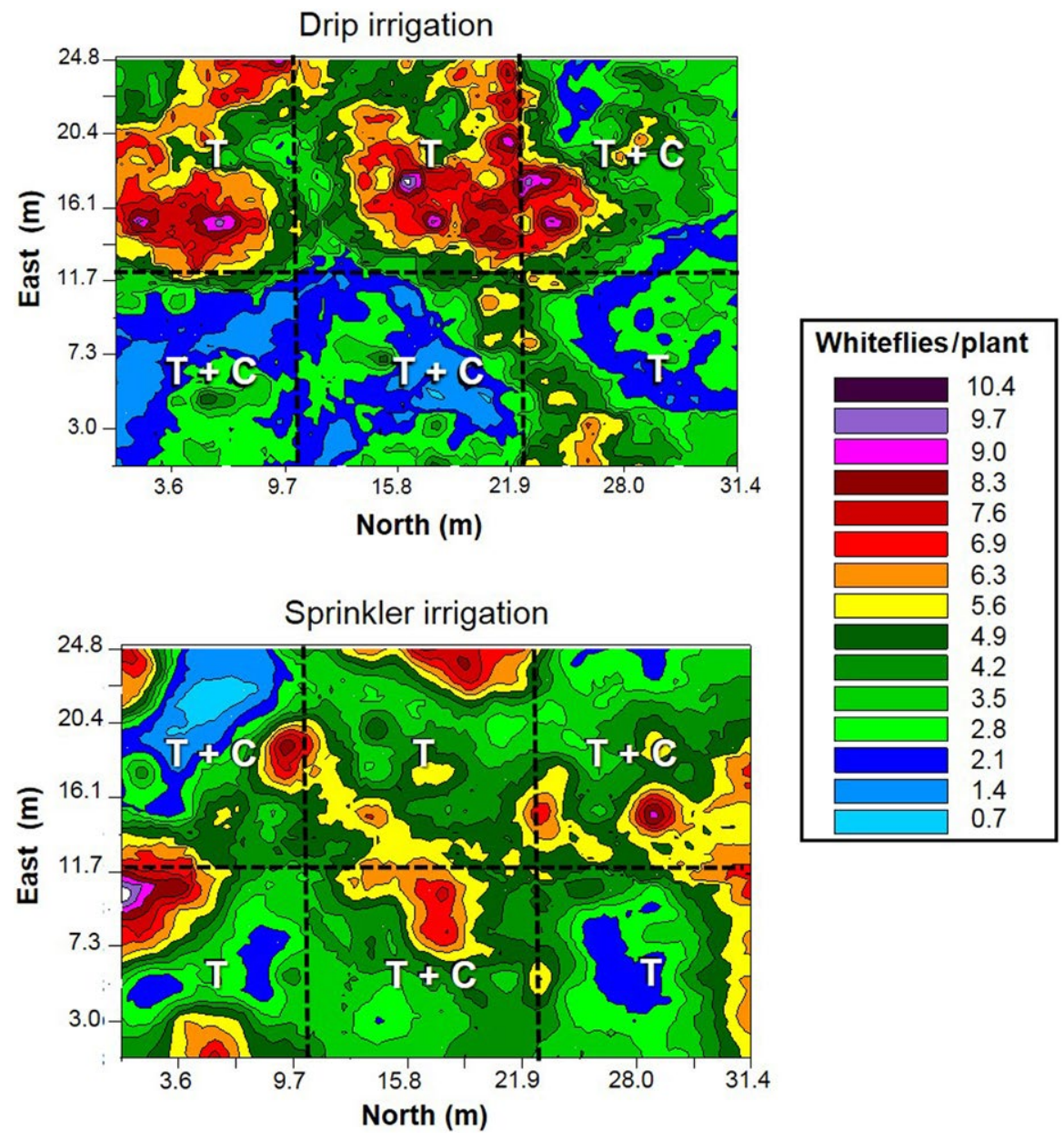

FIGURE 2 Contour maps of density distribution patterns of adult whiteflies sampled directly from tomato plants on the fifth week after transplanting in plots irrigated by sprinkler or drip systems in an organic crop system in the Federal District, Brazil. " $T$ " indicates plots with tomatoes planted in monoculture, and " $\mathrm{T}+\mathrm{C}$ " indicates plots with tomatoes intercropped with coriander plants. The average number of whiteflies per plant is represented by colours that vary from light blue (low density) to purple (high densities) [Colour figure can be viewed at wileyonlinelibrary.com]

\section{3 | RESULTS}

\section{1 | Intercropping with coriander and whitefly spatial distribution}

All individuals tested using RAPD markers were identified as $B$. tabaci MEAM1. The mean number of adult whiteflies was $20.42 \%$ higher in monoculture plots than in intercropped plots (Figure 1). Similarly, the

number of nymphs per plant was $41.20 \%$ higher in monoculture than in intercropped plots (Figure 1). These differences were significant for both adults and nymphs $\left(F_{1,49}=52.86, p<0.0001 ; F_{1,39}=38.87\right.$, $p<0.0001$, respectively). This means that the presence of coriander plants negatively impacted the abundance of $B$. tabaci in tomato plants.

The contour maps that were constructed based on the abundance of individuals showed that there was a tendency for adult 
whiteflies to aggregate on monoculture plots, mainly when plots were irrigated by the drip system. In plots irrigated by sprinklers, there was a tendency for distribution on random clusters (Figure 2). When constructing the contour maps of B. tabaci distribution, spatial dependency was achieved by fitting an exponential model in the drip irrigated plots and a linear model in the sprinkler-irrigated plots (model parameters: $R^{2}=0.92, C_{0}=1.70, C_{0}+C=6.92$, $a=1.80, C_{0} / C_{0}+C=0.75$; model parameters: $R^{2}=0.60, C_{0}=2.36$, $C_{0}+C=3.77, a=4.40, \quad C_{0} / C_{0}+C=0.38$, respectively). Contour maps were then constructed through interpolation of the abundance data of adults per plant, using the results of these models. These models best fit the observed data with the theoretical semivariogram model.

\section{2 | Intercropping with coriander and irrigation management}

In the second experiment, the previously observed effects of the irrigation system on adult and nymph abundance were confirmed. The population density of adult whiteflies was higher on monoculture plots irrigated by the drip system and lower on plots with tomato intercropped with coriander irrigated by the sprinkler system (Figure 3a). The adults' abundance was significant affected by the cropping scheme and irrigation management $\left(F_{1,56}=9.45, p=0.0027\right.$; $F_{1,56}=12.01, p=0.0008$, respectively). No interaction between these variables was observed $\left(F_{1,56}=2.36, p=0.127\right)$. Following a similar trend, intercropping with coriander reduced nymph density in both irrigation systems, but it was more effective when tomato plants were irrigated with the sprinkler system than with the drip system (Figure 3b). Tomato plants intercropped with coriander and irrigated by the drip system had a density of nymphs per plant that was equivalent to the monoculture plants irrigated by the sprinkler system. Nymph density was affected by the cropping scheme and the irrigation system $\left(F_{1,89}=43.11, p<0.0001 ; F_{1,89}=32.79\right.$, $p<0.0001$, respectively). Different from the adults, there was a significant interaction between the cropping scheme and the irrigation system on nymph abundance $\left(F_{1,89}=4.17, p=0.0442\right)$.

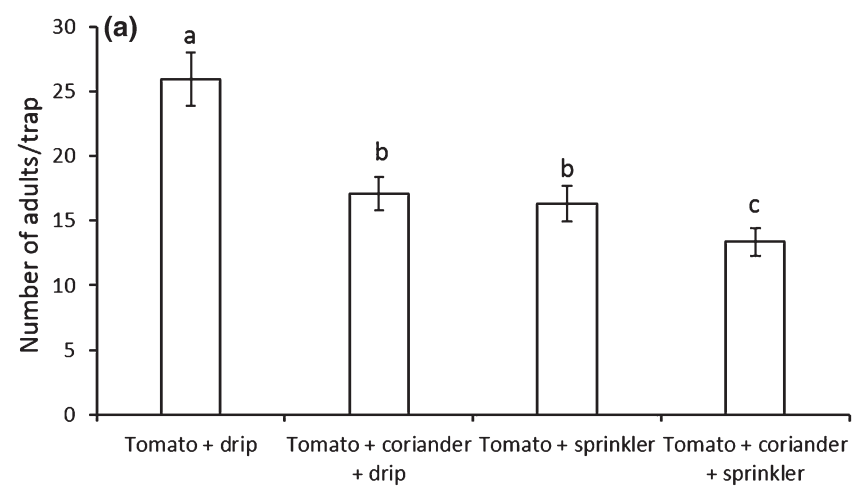

\section{3 | Begomovirus incidence}

Tomato plants in the monoculture system and the drip-irrigated system presented more infected plants than did plants in other treatments. Moreover, the lowest incidence of begomovirus-infected tomato plants was observed in the tomato-coriander intercrop, regardless of the irrigation system (Figure $4 \mathrm{~b}$ ). In both years, the only begomovirus found in the plants was Tomato severe rugose virus, and its incidence was considered low (<20\%). The incidence of the begomovirus disease was affected by the cropping scheme in the first experiment and second experiment $\left(F_{1,9}=15.78, p=0.0032 ; F_{1,5}=17.39, p<0.001\right.$, respectively), with a higher incidence in monoculture plots (Figure $4 a$ ).

\section{DISCUSSION}

The significant reduction in B. tabaci populations observed in the present study by intercropping tomato plants with coriander plants confirmed the patterns observed by Hilje and Stansly (2008) and Togni et al. (2009), who tested the same intercrop in conventional farming systems in Costa Rica and Brazil, respectively. Hilje and Stansly (2008) argue that coriander plants may hide the shorter tomato plants at the beginning of the tomato crop. Thus, coriander visually masks the tomato plants for long distances, which can make it difficult for B. tabaci to find its host and reduces whitefly colonization (Hilje \& Stansly, 2008). At shorter distances, plant volatiles are known to play a role in habitat recognition (Bleeker et al., 2009, 2011). In this case, odours from coriander plants may have masked the odour of the tomato plants, thereby interfering with the ability of the whiteflies to find their host (Carvalho, Bortolotto, \& Ventura, 2017; Togni, Laumann, et al., 2010). Volatiles from nonhost plant or a poor host plant such as the coriander may act as a negative or a confounding factor that reduces the arrestant stimulus from tomato plants, and whiteflies tend to move to another patch where more reliable signal might be found (i.e., only volatiles from tomato plants; Togni, Laumann, et al., 2010). This resulted in lower oviposition rates, as measured by nymph densities, and reduced crop colonization (Togni, Laumann, et al., 2010).

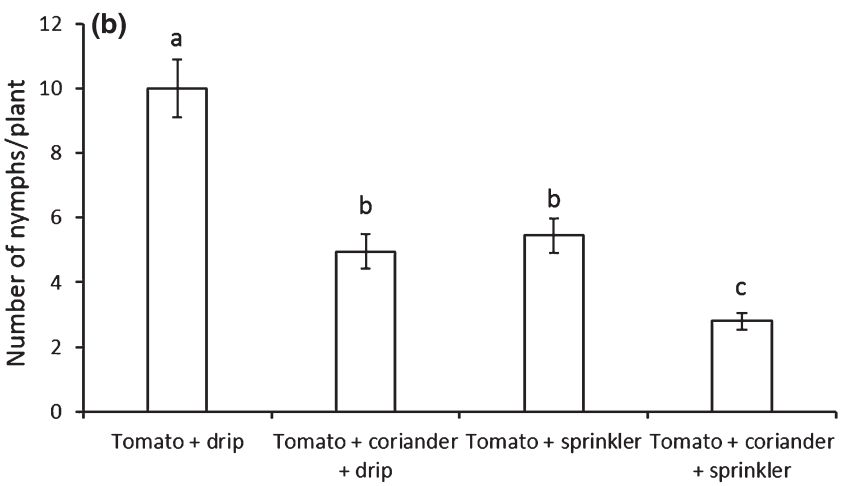

FIGURE 3 Number of adult whiteflies per yellow sticky trap (mean $\pm S E$ ) (a) and number of nymphs (mean \pm SE) per plant (b) on tomato crops planted in monoculture or intercropped with coriander, irrigated by the drip or sprinkler system in an organic system in the Federal District, Brazil. Means followed by the same letter do not differ significantly by model contrast analysis $(p>0.05)$ 


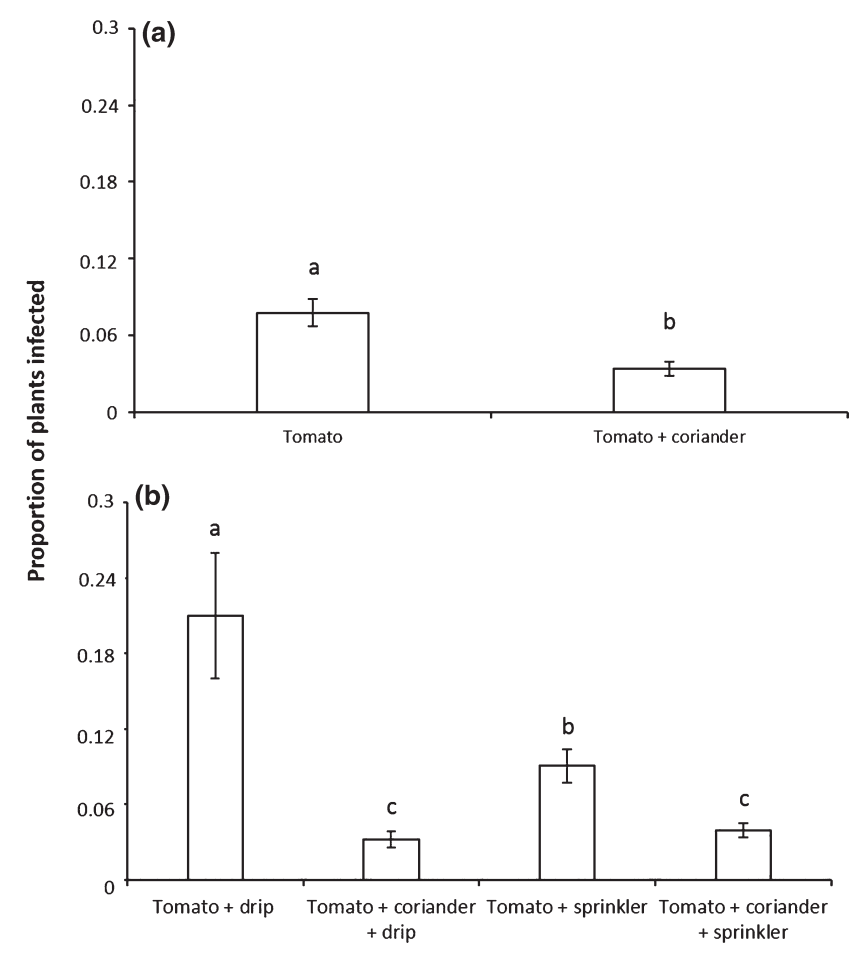

FIGURE 4 Proportion of tomato plants infected with Begomovirus when cropped in monoculture and intercropped with coriander in 2008 (a) and cropped in monoculture and intercropped with coriander with drip or sprinkler irrigation system in 2009 (b) in an organic crop system. Experiments were conducted in the Federal District, Brazil

Based on the contour map analyses, aggregation of adult whiteflies was more frequently observed in monoculture plots, and under drip irrigation. When dealing with multiple sensory stimuli (i.e., plant volatiles, habitat structure and visual stimulus), B. tabaci tends to move more frequently between plants until making a decision to feed and reproduce in a given plant (Bird \& Krüger, 2006). For example, the presence of various weed hosts in tomato crops tends to cause a "dilution" of the attractiveness of tomato plants as hosts of B. tabaci, so the population is more scattered in the cropping area (Bezerra, Oliveria, \& Vasconcelos, 2004). This increase in movement due to habitat structure in intercropped plots increases phytophagous vulnerability to predators (Straub et al., 2014), and B. tabaci is known to avoid patches with a predation risk (Lee, Nyrop, \& Sanderson, 2011). All these factors may have contributed to adults aggregating on monoculture plots. We also observed that sprinkler-irrigated plots produced random clusters of adult aggregation, mainly in the intercropped plots. These results indicate that the combination of factors that disorient (coriander) and disturb (direct impact of water) B. tabaci behaviour affect the spatial distribution of the insects.

In the second trial, the use of overhead sprinklers increased the negative effects of intercropping with coriander on $\mathrm{B}$. tabaci adults and nymph's abundance. Two factors may have contributed to this pattern. First, the water applied above the tomato canopy could have dislodged nymphs (Castle et al., 1996), similar to the observed reduction in nymph densities due to surface wetness and the impact of the water drops after rainfall (Hilje, Costa, \& Stansly, 2001). Nymph dislodgment was previously identified as an important factor contributing to whitefly mortality in cassava (Asiimwe et al., 2007) and cotton (Karut \& Naranjo, 2009; Naranjo \& Ellsworth, 2005) cultivations. Second, adult whiteflies need to probe a plant for $18.3 \pm 12.9 \mathrm{~min}$ (mean $\pm S D$ ) to accept or reject it as a host (Walker, Perring, \& Freeman, 2010). Individuals disturbed during the process of water applied by overhead sprinklers may be more likely to move to another plant or patch. Based on this assumption and on the "appropriate" and "inappropriate" landing concept proposed by Finch and Collier (2000), we suggest that the overhead irrigation management system strongly and negatively affects the appropriateness of the tomato plants as landing and oviposition sites. This concept predicts that the host plant selection of insects depends on a three-link chain involving the recognition of volatile plant chemicals, visual stimuli and nonvolatile plant chemicals. When attracted to a given area, the insect moves among plants and evaluates these different sources of information as a positive or a negative stimulus. As more negative stimuli are encountered (inappropriate landing), the individual tends to move more frequently to another plant or patch without laying eggs (Finch \& Collier, 2000). In this sense, water drops could act as negative stimuli that make whitefly decision-making difficult. Considering that habitat structure and connectivity is a determinant for B.tabaci movement (Abdelkrim, Hattab, Fakhfakh, Belkadhi, \& Gorsane, 2017), coriander can also hinder adult movement between plants, while sprinkler irrigation hinders population establishment due to a physical effect over adults and nymphs at the plot scale.

The plots with tomato plants intercropped with coriander consistently contained fewer Tomato severe rugose virus-infected plants than the monoculture plots throughout the study in both years. Similar results with coriander plants were observed in Costa Rica (Hilje \& Stansly, 2008). Recent studies have consistently demonstrated that cultural practices, mainly intercropping, can reduce different begomovirus incidences and spread on cassava (Fundong, Thresh, \& Zok, 2002; Maruthi et al., 2016; Uzokwe et al., 2016) and horticultural crops, such as cucumber, squash and tomato (Abd-Rabou \& Simmons, 2012). Sprinkler irrigation also had an effect on reducing tomato infection and virus incidences. Similarly, sprinkler irrigation reduced begomovirus incidence on common beans in Brazil (Lima, Assunção, Teodoro, Lima, \& Michereff, 2011). Thus, irrigation system management is another cultural practice that can be incorporated into organic tomato crop systems to reduce virus damage. We hypothesize that an increase in the movement of adults caused by the intercropping with coriander plants and the use of sprinkler irrigation may have reduced the time needed to efficiently transmit the virus to the tomato plants.

In conclusion, integration of coriander intercropping and use of a sprinkler irrigation into organic tomato agroecosystems can be used to reduce $B$. tabaci colonization and begomovirus damage 
during the most susceptible growth phase of the crop. The intercropping interferes in the tomato-whitefly interaction by means of both visual and olfactory signals (Hilje et al., 2001; Togni, Laumann, et al., 2010), and sprinkler irrigation physically interferes in adult establishment and dispersion into the crop. Combined, these two strategies can be considered effective environmentally friendly tools for the management of a worldwide pest in organic farming. This strategy should be considered and tested also as a management method integrated with chemical insecticide control of whiteflies and begomoviruses in conventional farming systems. Nevertheless, understanding how and why cultural practices affect insect-plant interactions is imperative to ensure the effectiveness of such pest management strategies in ecologically based organic farming systems.

\section{ACKNOWLEDGEMENTS}

The authors are grateful to KR Cavalcante and LF Langer for field assistance and data collection. To MA Medeiros, FV Resende, RS de Liz, JR Couto and all the people that worked at the Embrapa Hortaliças experimental field for technical assistance during the experiment conduction. PQ Silva is acknowledged for molecular identification of the whiteflies. This study was supported by research grants and fellowships to the authors from the Conselho Nacional de Desenvolvimento Científico e Tecnológico (CNPq) and by research grants from the Fundação de Amparo à Pesquisa do Distrito Federal (FAP-DF), and Centro de Desenvolvimento Tecnológico da Agricultura Orgânica no Distrito Federal (CDTOrg-DF). AKIN is a CNPq fellow.

\section{AUTHOR CONTRIBUTION}

PHBT, ERS and WAM conceived the study. PHBT and WAM collected the data. WAM installed the experiment and irrigation systems. AKIN performed the molecular analysis. PHBT, ERS and CSSP analysed the data, and PHBT and ERS conducted statistical analyses. PHBT drafted the manuscript. All authors discussed the results and critically revised the manuscript prior to approval of the final version.

\section{ORCID}

Pedro Henrique Brum Togni iD http://orcid.org/0000-0003-3488-0694

\section{REFERENCES}

Abdelkrim, A. B., Hattab, T., Fakhfakh, H., Belkadhi, M. S., \& Gorsane, F. (2017). A landscape genetic analysis of important agricultural pest species in Tunisia: The whitefly Bemisia tabaci. PLoS One, 12, e0185724. https://doi.org/10.1371/journal.pone.0185724

Abd-Rabou, S., \& Simmons, A. M. (2012). Some cultural strategies to help manage Bemisia tabaci (Hemiptera: Aleyrodidae) and whiteflytransmitted viruses in vegetable crops. African Entomology, 20, 371379. https://doi.org/10.4001/003.020.0201
Angelella, G. M., Holland, J. D., \& Kaplan, I. (2016). Landscape composition is more important than local management for crop virus-insect vector interactions. Agriculture, Ecosystems and Environment, 233, 253-261. https://doi.org/10.1016/j.agee.2016.09.019

Asiimwe, P., Ecaat, J. S., Otim, M., Gerling, D., Kyamanywa, S., \& Legg, J. P. (2007). Life-table analysis of mortality factors affecting populations of Bemisia tabaci on cassava in Uganda. Entomologia Experimentalis et Applicata, 122, 37-44. https://doi. org/10.1111/j.1570-7458.2006.00487.x

Bezerra, M. A. S., Oliveria, M. R. V., \& Vasconcelos, S. D. (2004). Does the presence of weeds affect Bemisia tabaci (Gennadius) (Hemiptera: Aleyrodidae) infestation on tomato plants in a semi-arid agroecosystem? Neotropical Entomology, 33, 769-775. https://doi. org/10.1590/S1519-566X2004000600015

Bird, T. L., \& Krüger, K. (2006). Response of the polyphagous whitefly Bemisia tabaci B-biotype (Hemiptera: Aleyrodidae) to crop diversification - Influence of multiple sensory stimuli on activity and fecundity. Bulletin of Entomological Research, 96, 15-23. https://doi. org/10.1079/BER2005398

Bleeker, P. M., Diergaarde, P. J., Ament, K., Guerra, J., Weidner, M., Schütz, S., ... Schuurink, R. C. (2009). The role of specific tomato volatiles in tomato-whitefly interaction. Plant Physiology, 151, 925-935. https://doi.org/10.1104/pp.109.142661

Bleeker, P. M., Diergaarde, P. J., Ament, K., Schütz, S., Johne, B., Dijkink, J., ... Schuurink, R. C. (2011). Tomato-produced 7-epizingiberene and R-curcumene act as repellents to whiteflies. Phytochemistry, 72, 6873. https://doi.org/10.1016/j.phytochem.2010.10.014

Brewster, C. C., Allen, J. C., Schuster, D. J., \& Stansly, P. A. (1997). Simulating the dynamics of Bemisia argentifolii (Homoptera: Aleyrodidae) in an organic cropping system with a spatiotemporal model. Environmental Entomology, 26, 603-616. https://doi. org/10.1093/ee/26.3.603

Byrne, D. N. (1999). Migration and dispersal by the sweet potato whitefly, Bemisia tabaci. Agricultural and Forest Meterorology, 97, 309-316. https://doi.org/10.1016/S0168-1923(99)00074-X

Byrne, D. N., \& Bellows, T. S. Jr (1991). Whitefly biology. Annual Review of Entomology, 36, 431-457. https://doi.org/10.1146/annurev. en.36.010191.002243

Carvalho, M. G., Bortolotto, O. C., \& Ventura, M. U. (2017). Aromatic plants affect the selection of host tomato plants by Bemisia tabaci biotype B. Entomologia Experimentalis et Applicata, 162, 86-92. https://doi.org/10.1111/eea.12534

Castle, S. J., Henneberry, T. J., \& Toscano, N. C. (1996). Suppression of Bemisia tabaci (Homoptera: Aleyrodidae) infestations in cantaloupe and cotton with sprinkler irrigation. Crop Protection, 15, 657-663. https://doi.org/10.1016/0261-2194(96)00037-3

Crawley, M. J. (2007). The R book. Chichester, UK: Wiley. https://doi. org/10.1002/9780470515075

Czosnek, B., Ghanim, M., \& Ghanim, M. (2002). The circulative pathway of begomoviruses in the whitefly vector Bemisia tabaci - Insights from studies with Tomato yellow leaf curl virus. Annals of Applied Biology, 140, 215-231. https://doi.org/10.1111/j.1744-7348.2002. tb00175.x

Díaz-Pendón, J. A., Cañizares, M. C., Moriones, E., Bejarano, E. R., Czosnek, H., \& Navas-Castillo, J. (2010). Tomato yellow leaf curl viruses: Ménage à trois between the virus complex, the plant and the whitefly vector. Molecular Plant Pathology, 11, 441-450. https://doi. org/10.1111/j.1364-3703.2010.00618.x

EFSA (2013). EFSA Panel on Plant Health (PLH): Scientific opinion on the risks to plant health posed by Bemisia tabaci species complex and viruses it transmits for the EU territory. EFSA Journal, 11, 3162.

Embrapa (2014). Cultivares da Embrapa Hortaliças (1981-2013). Brasília, Brazil: Embrapa.

Finch, S., \& Collier, R. H. (2000). Host-plant selection by insects - A theory based on 'appropriate/inappropriate landings' by pest insects 
of cruciferous plants. Entomologuia Experimentalis et Applicata, 96, 91-102. https://doi.org/10.1046/j.1570-7458.2000.00684.x

Fundong, V. N., Thresh, J. M., \& Zok, S. (2002). Spatial and temporal spread of cassava mosaic virus disease in cassava grown alone and when intercropped with maize and/or cowpea. Journal of Phytopathology, 150, 365-374. https://doi. org/10.1046/j.1439-0434.2002.00775.x

Ghanim, M., \& Medina, V. (2007). Localization of tomato yellow leaf curl virus in its whitefly vector Bemisia tabaci. In $\mathrm{H}$. Czosnek (Ed.), Tomato yellow leaf curl virus disease: Management, molecular biology, breeding for resistance (pp. 171-183). Dordrecht, The Netherlands: Springer. https://doi.org/10.1007/978-1-4020-4769-5

Gilbertson, R. L., Batuman, O., Webster, C. G., \& Adkins, S. (2015). Role of the insect supervectors Bemisia tabaci and Frankliniella occidentalis in the emergence and global spread of plant viruses. Annual Review of Virology, 2, 67-93. https://doi.org/10.1146/ annurev-virology-031413-085410

Giordano, L. B., Fonseca, M. E. N., Silva, J. B. C., Inoue-Nagata, A. K., \& Boiteux, L. S. (2005). Efeito da infecção precoce por Begomovirus com genoma bipartido em características de frutos de tomate industrial. Horticultura Brasileira, 23, 815-818. https://doi.org/10.1590/ S0102-05362005000300025

Hilje, L., Costa, H. S., \& Stansly, P. A. (2001). Cultural practices for managing Bemisia tabaci and associated viral diseases. Crop Protection, 20, 801-812. https://doi.org/10.1016/S0261-2194(01)00112-0

Hilje, L., \& Stansly, P. A. (2008). Living ground covers for management of Bemisia tabaci (Gennadius) (Homoptera: Aleyrodidae) and tomato yellow mottle virus (ToYMoV) in Costa Rica. Crop Protection, 27, 1016. https://doi.org/10.1016/j.cropro.2007.04.003

Inoue-Nagata, A. K., Albuquerque, L. C., Rocha, W. B., \& Nagata, T. (2004). A simple method for cloning the complete begomovirus genome using the bacteriophage $\varphi 29$ DNA polymerase. Journal of Virological Methods, 116, 209-211. https://doi.org/10.1016/j. jviromet.2003.11.015

Isaacs, R., Willis, M. A., \& Byrne, D. N. (1999). Modulation of whitefly take-off and flight orientation by wind speed and visual cues. Physiological Entomology, 24, 311-318. https://doi. org/10.1046/j.1365-3032.1999.00144.x

Jones, D. (2003). Plant viruses transmitted by whiteflies. European Journal of Plant Pathology, 109, 195-219. https://doi. org/10.1023/A:1022846630513

Karut, K., \& Naranjo, S. E. (2009). Mortality factors affecting Bemisia tabaci populations on cotton in Turkey. Journal of Applied Entomology, 133, 367-374. https://doi.org/10.1111/j.1439-0418.2008.01369.x

Lee, D. H., Nyrop, J. P., \& Sanderson, J. P. (2011). Avoidance of natural enemies by adult whiteflies, Bemisia argentifolii, and effects on host plant choice. Biological Control, 58, 302-309. https://doi. org/10.1016/j.biocontrol.2011.06.005

Liebhold, A. M., Rossi, R. E., \& Kemp, W. P. (1993). Geostatistics and geographic information systems in applied insect ecology. Annual Review of Entomology, 38, 303-327. https://doi.org/10.1146/annurev. en.38.010193.001511

Lima, J.S., Assunção, I. P., Teodoro, I., Lima, G. S. A., \& Michereff, S. J. (2011). Influência do sistema de irrigação na incidência e nas perdas ocasionadas pelo Mosaico Dourado do Feijoeiro. Tropical Plant Pathology, 36, 50-53. https://doi.org/10.1590/S1982-56762011000100008

Lima, L. H. C., Campos, L., Moretzsohn, M. C., Návia, D., \& Oliveira, M. R. V. (2002). Genetic diversity of Bemisia tabaci (Genn.) populations in Brazil revealed by RAPD markers. Genetics and Molecular Biology, 25, 217-223. https://doi.org/10.1590/ S1415-47572002000200016

Liu, B., Preisser, E. L., Chu, D., Pan, H., Xie, W., Wang, S., ... Zhang, Y. (2013). Multiple forms of vector manipulation by a plant-infecting virus: Bemisia tabaci and Tomato Yellow Leaf Curl Virus. Journal of Virology, 87, 4929-4937. https://doi.org/10.1128/JVI.03571-12
Marouelli, W. A., Carrijo, O. A., Souza, R. B., \& Silva, W. L. C. (2011). Irrigação e fertirrigação na cultura do tomate. In V. F. Sousa, W. A. Marouelli, E. F. Coelho, J. M. Pinto, \& M. A. Coelho-Filho (Eds.), Irrigação e fertirrigação em fruteiras e hortaliças (pp. 739-769). Brasília, Brasil: Embrapa Informação Tecnológica.

Marouelli, W. A., Medeiros, M. A., Souza, R. F., \& Resende, F. V. (2011). Produção de tomateiro orgânico irrigado por aspersão e gotejamento, em cultivo solteiro e consorciado com coentro. Horticultura Brasileira, 29, 429-434. https://doi.org/10.1590/S0102-05362011000300029

Maruthi, M. N., Jeremiah, S. C., \& Muhammed, I. U. (2016). The role of the whitefly, Bemisia tabaci (Gennadius), and farmer practices in the spread of cassava brown streak ipomoviruses. Journal of Phytopathology, 165, 707-717.

Naranjo, S. E., \& Ellsworth, P. C. (2005). Mortality dynamics and population regulation in Bemisia tabaci. Entomologia Experimentalis et Applicata, 116, 93-108. https://doi.org/10.1111/(ISSN)1570-7458

Navas-Castillo, J., Fiallo-Olivé, E., \& Sánchez-Campos, S. (2011). Emerging virus diseases transmitted by whiteflies. Annual Review of Phytopathology, 49, 219-248. https://doi.org/10.1146/ annurev-phyto-072910-095235

Nimer, E., \& Brandão, A. M. P. M. (1989). Balanço hídrico e clima da região dos cerrados. Rio de Janeiro: IBGE.

Ning, W., Shi, X., Baiming, L., Pan, H., Wei, W., Zeng, Y., ... Zhang, Y. (2015). Transmission of Tomato Yellow Leaf Curl Virus by Bemisia tabaci as affected by whitefly sex and biotype. Scientific Reports, 5, 10744. https://doi.org/10.1038/srep10744

Oliveira, C. M., Auad, A. M., Mendes, S. M., \& Frizzas, M. R. (2013). Economic impact of exotic insect pests in Brazilian agriculture. Journal of Applied Entomology, 137, 1-15. https://doi.org/10.1111/jen.12018

Oliveira, M. R. V., Henneberry, T. J., \& Anderson, P. (2001). History, current status, and collaborative research projects for Bemisia tabaci. Crop Protection, 20, 709-723. https://doi.org/10.1016/ S0261-2194(01)00108-9

Pakkianathan, B. C., Kontsedalov, S., Lebedev, V., Mahadav, A., Zeidan, M., Czosnek, H., \& Ghanim, M. (2015). Replication of Tomato Yellow Leaf Curl Virus in its whitefly vector, Bemisia tabaci. Journal of Virology, 89, 9791-9803. https://doi.org/10.1128/JVI.00779-15

Polston, J. E., Chellemi, D. O., Schuster, D. J., McGovern, R. J., \& Stansly, P. A. (1996). Spatial and temporal dynamics of tomato mottle geminivirus and Bemsia tabaci (Genn.) in Florida tomato fields. Plant Disease, 80, 1022-1028. https://doi.org/10.1094/PD-80-1022

R Core Team (2017). R: A language and environment for statistical computing. Vienna, Austria: R Foundation for Statistical Computing.

Riis, L., \& Nachman, G. (2006). Migration, trapping and local dynamics of whiteflies (Homoptera: Aleyrodidae). Agrivultural and Forest Meteorology, 8, 233-241.

Sousa, A. A. T. C., Souza, L. M., Togni, P. H. B., Vieira, L., Carneiro, R. G., Fontes, E. M. G., ... Sujii, E. R. (2016). Diagnóstico dos problemas fitossanitários na agricultura de base ecológica no Distrito Federal e entorno. Brasília, Brazil: Documentos Embrapa, Documento No 350.

Straub, C. S., Simasek, N. P., Dohm, R., Gapinski, M. R., Aikens, E. O., \& Nagy, C. (2014). Plant diversity increases herbivore movement and vulnerability to predation. Basic and Applied Ecology, 15, 50-58. https://doi.org/10.1016/j.baae.2013.12.004

Togni, P. H. B., Cavalcante, K. R., Langer, L. F., Gravina, C. S., Medeiros, M. A., Pires, C. S. S., ... Sujii, E. R. (2010). Conservação de inimigos naturais (Insecta) em tomateiro orgânico. Arquivos do Instituto Biológico, 77, 669-679.

Togni, P. H. B., Frizzas, M. R., Medeiros, M. A., Nakasu, E. Y. T., Pires, C. S. S., \& Sujii, E. R. (2009). Dinâmica populacional de Bemisia tabaci biótipo $\mathrm{B}$ em tomate monocultivo e consorciado com coentro sob cultivo orgânico e convencional. Horticultura Brasileira, 27, 183-188. https://doi.org/10.1590/S0102-05362009000200011

Togni, P. H. B., Laumann, R. A., Medeiros, M. A., \& Sujii, E. R. (2010). Odour masking of tomato volatiles bycoriandervolatilesinhostplantselection 
of Bemisia tabaci biotype B. Entomologia Experimentalis et Applicata, 136, 164-173. https://doi.org/10.1111/j.1570-7458.2010.01010.x

Uzokwe, V. N. E., Mlay, D. P., Masunga, H. R., Kanju, E., Odeh, I. O. A., \& Onyeka, J. (2016). Combating viral mosaic disease of cassava in the Lake Zone of Tanzania by intercropping with legumes. Crop Protection, 84, 69-80. https://doi.org/10.1016/j.cropro.2016.02.013

Walker, G., Perring, T., \& Freeman, T. (2010). Life history, functional anatomy, feeding and mating behavior. In P. A. Stansly, \& S. E. Naranjo (Eds.), Bemisia: Bionomics and management of a global pest (pp. 109160). Dordrecht, The Netherlands: Springer.
How to cite this article: Togni PHB, Marouelli WA, InoueNagata AK, Pires CSS, Sujii ER. Integrated cultural practices for whitefly management in organic tomato. J Appl Entomol. 2018;142:998-1007. https://doi.org/10.1111/jen.12558 